Rice University's Baker Institute

LATIN AMERICA INITIATIVE

RICE UNIVERSITY'S 20 YEARS

BAKER INSTITUTE 201993-2013
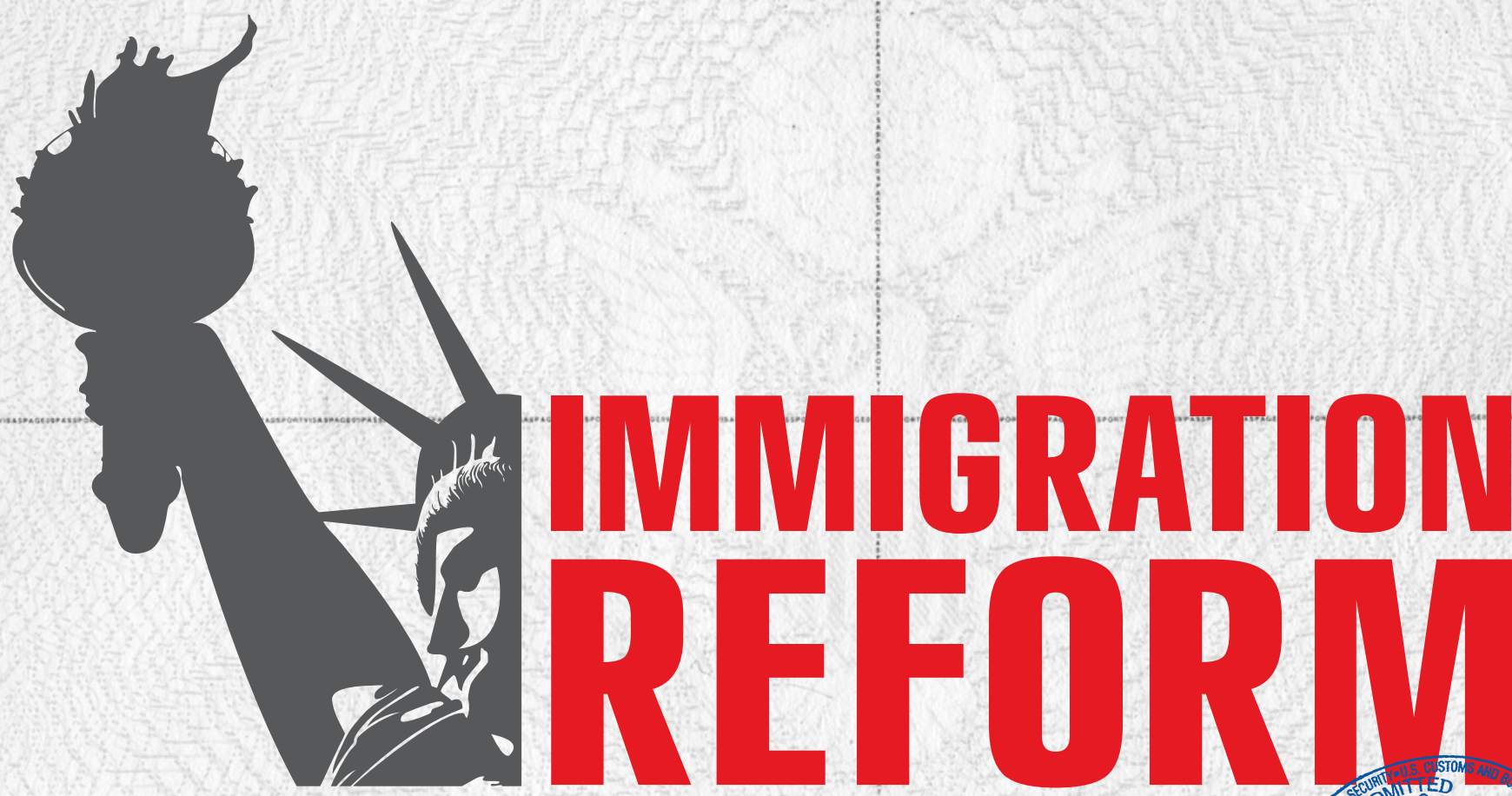

A SYSTEM FOR THE 21st CENTURY

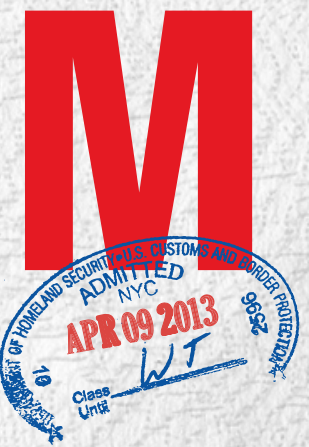

The Immigration Debate in Texas

Tony Payan, Ph.D. 


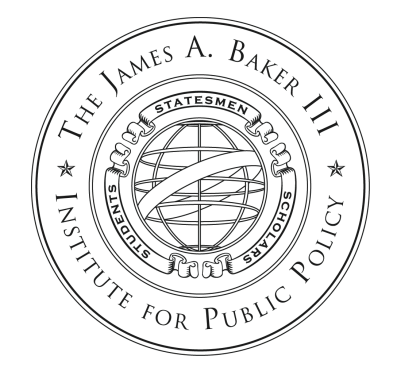

JAMES A. BAKER III INSTITUTE FOR PUBLIC POLICY

RICE UNIVERSITY

LATIN AMERICA INITIATIVE IMMIGRATION RESEARCH PROJECT WORKING PAPER

\section{The IMmigration Debate IN TEXAS}

BY

TONy Payan, Ph.D.

FELLOW IN IMMIGRATION AND BORDER STUdies

RICE UNIVERSITY'S BAKER INSTITUTE

APRIL 2013 
The Immigration Debate in Texas

THESE PAPERS WERE WRITTEN BY A RESEARCHER (OR RESEARCHERS) WHO PARTICIPATED IN A

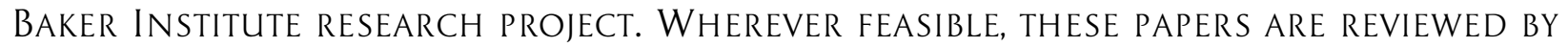
OUTSIDE EXPERTS BEFORE THEY ARE RELEASED. HOWEVER, THE RESEARCH AND VIEWS EXPRESSED IN THESE PAPERS ARE THOSE OF THE INDIVIDUAL RESEARCHER(S), AND DO NOT NECESSARILY REPRESENT THE VIEWS OF THE JAMES A. BAKER III INSTITUTE FOR PUBLIC POLICY.

(C) 2013 By the James A. BAker III Institute for P UbliC POlicy Of RiCe University

THIS MATERIAL MAY BE QUOTED OR REPRODUCED WITHOUT PRIOR PERMISSION, PROVIDED APPROPRIATE CREDIT IS GIVEN TO THE AUTHOR AND THE JAMES A. BAKER III INSTITUTE FOR PUBLIC POLICY. 
The Immigration Debate in Texas

\begin{abstract}
The failure of the U.S. Congress to deal with immigration reform prompted many local governments to craft their own responses to the presence of undocumented immigrants in their communities. The federal government's lack of leadership led to local responses that ranged from protective to punitive. Although some states like Arizona went to the extreme to create a hostile environment for undocumented migrants, other states and local governments were much more moderate. Local responses to undocumented immigrants depended on a number of variables, including demographics, political leadership, economic forces, and historical variables. The state of Texas, like other state governments, produced its own response to undocumented migration, and many counties and cities in the state joined in the heated debates of the previous decade with their own ordinances. The final landscape was quite uneven, with somewhat generous initiatives mixed with others that were quite harsh. Texas' response could be considered moderate when compared to other states. This paper explores state and local initiatives in Texas to explain why the overall environment in Texas remains moderate when so many other states have responded harshly to undocumented immigration.
\end{abstract}

\title{
Introduction
}

The failure of the U.S. Congress to deal with immigration reform prompted many state and local governments to craft their own responses to the presence of large and growing numbers of undocumented residents. The responses varied by state, with some being relatively generous and others highly punitive. In July 2011, for example, Gov. Jerry Brown of California signed AB 130, a bill that allowed undocumented students enrolled in California's public colleges and universities to receive privately funded university scholarships from nonstate funds. Later, California also passed a companion bill, AB 131, which allowed undocumented students to apply for state-sponsored financial aid. At the opposite end of the spectrum is Arizona. In 2010, the Arizona legislature passed an immigration reform bill, SB-1070, which required police to determine the legal status of individuals during a lawful stop, criminalized working or attempting to work without authorization, and authorized Arizona law enforcement officers to make a warrantless arrest for the commission of a removable offense, among other provisions. The passage of the Arizona law encouraged other state and municipal governments to pass harsh anti- 
immigration legislation - a development some observers called the "Arizonification" of immigration law (Cianciarulo 2012). Local responses to the immigration crisis depended on a number of variables, including demographics, political leadership, party, economic forces, and historical factors.

The final landscape was quite uneven, with somewhat generous initiatives mixed with others there were quite harsh. In the midst of what became a chaotic debate on immigration and a flurry of local and state initiatives - mostly punitive toward undocumented migrants-Texas' response could be considered quite moderate. It is certainly so when compared to immigration initiatives in states such as Arizona, Mississippi, Georgia, Alabama, Indiana, South Carolina, Utah, and others. The response of the state of Texas - given the federal government's failure to stem the tide of undocumented migration and Congress' inability to pass immigration legislation-is rather counterintuitive, considering that Texas is both a passageway for much of that migration (it constitutes half of the 2000-mile U.S.-Mexico border) and a major recipient of undocumented migration, second only to California (see Table 1). The state's response is even more puzzling because Texas is considered a largely Republican, and the Republican Party has come to be associated with a hostile response to immigration, as other authors have shown (e.g., Jeong et al., 2011).

Table 1.

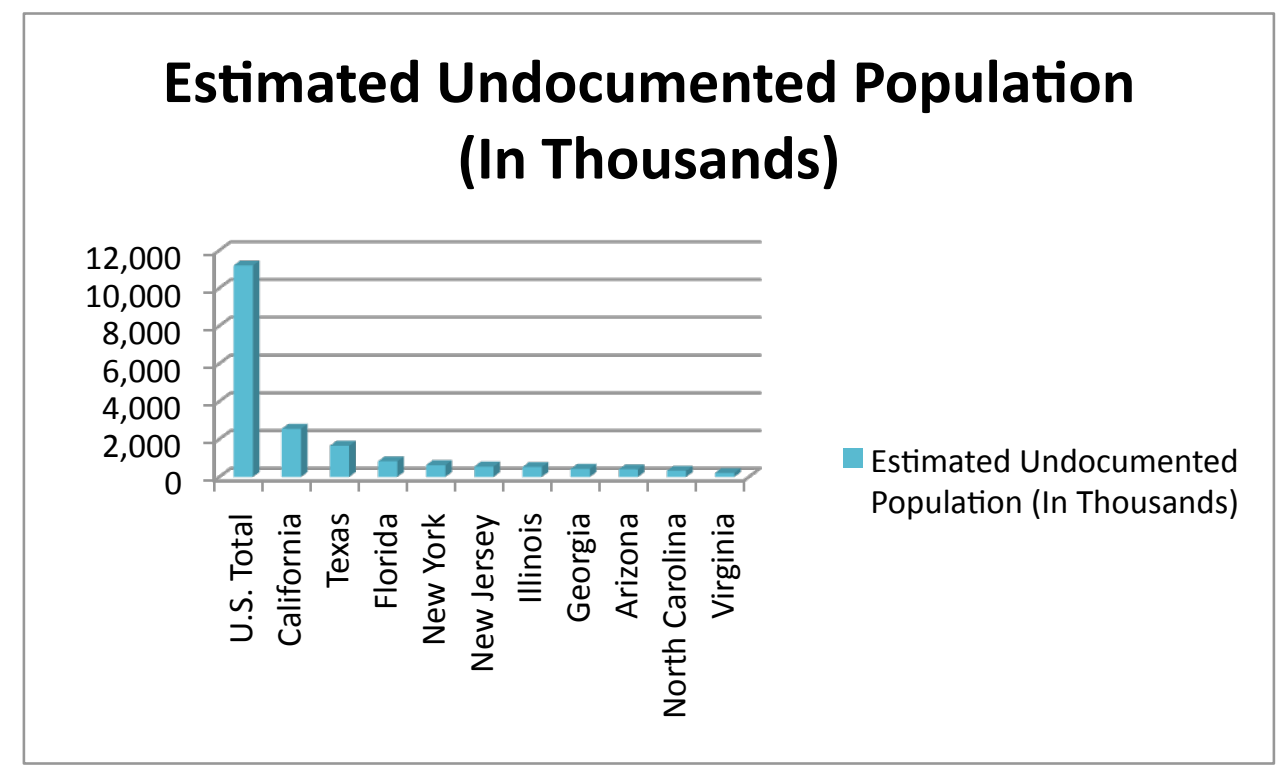

Source: Pew Hispanic Center estimates, 2010. 
This paper examines several factors that may explain why Texas stands, with a few local exceptions — such as the city of Farmers Branch, Texas ${ }^{1}$ - as a state of relative restraint when it comes to immigration.

To conduct analysis for the paper, data was gathered from 2009 and 2011-a period when the immigration debate in the United States was particularly contentious. In addition, the Texas legislature, which meets every other year, convened in 2009 and 2011. These were also the years when a majority of the most hostile state and local initiatives on immigration were passed across the country. The data consists of a series of bills introduced in the Texas House and Senate that primarily addressed immigrated-related issues. The paper focuses on the bills introduced in the state legislature, setting aside the patchwork of ordinances that emerged in certain cities and towns throughout the state.

To further the analysis and put the results into context, this paper also analyzes the 287(g) agreements-Immigration and Customs Enforcement (ICE) mechanisms of cooperation with local authorities on immigration enforcement — entered into by local governments in Texas.

Finally, the paper looks at the post-electoral political environment after President Barack Obama won reelection and the Republican Party largely changed the tone of its stands on immigration issues.

\section{Major Initiatives on Immigrants and Immigration in Texas}

This section provides details of the 19 immigration-related bills introduced in the Texas legislature during the 2009 and 2011 sessions. These bills are overwhelmingly related to employment verification, lawful presence status, law enforcement, government contracts, language, education, and cooperation with federal authorities (see Table 2 and Table 3 ).

\footnotetext{
${ }^{1}$ In 2006, the City of Farmers Branch, in the Dallas Metropolitan Area, was the first in Texas to pass anti-illegal immigration measures. It authorized the police to inquire into the legal status of detainees, curtailed the ability of apartment owners to rent to undocumented residents, eliminated subsidies for undocumented youth programs, and declared English the official language in the city. These measures were viewed as largely directed at the undocumented resident population of the city and reflected local frustration with the inability of the federal government to enforce immigration laws or reform the system.
} 
The Immigration Debate in Texas

Table 2. Immigration-related bills introduced by Texas legislators in 2009

\begin{tabular}{|c|c|c|c|c|c|c|}
\hline $\begin{array}{l}\text { Date } \\
\text { filed }\end{array}$ & Bill No. & Description & Keywords & $\begin{array}{l}\text { Passed: Y } \\
\text { or N }\end{array}$ & $\begin{array}{l}\text { Ratio for } \\
\text { or against }\end{array}$ & $\begin{array}{l}\text { Dem } \\
\text { or } \\
\text { Rep }\end{array}$ \\
\hline $\begin{array}{r}11 / 14 / 20 \\
08\end{array}$ & $\begin{array}{l}81(\mathrm{R})- \\
\text { HB } 233\end{array}$ & $\begin{array}{l}\text { The creation of an } \\
\text { advisory committee to } \\
\text { establish and recommend } \\
\text { qualifications for certain } \\
\text { health care translators } \\
\text { and interpreters. }\end{array}$ & $\begin{array}{l}\text { Language } \\
\text { Translators } \\
\text { Interpreters } \\
\text { Health care }\end{array}$ & Passed & $\begin{array}{l}95 / 48 \text { / } 1 \\
\text { in House; } \\
\text { Unani- } \\
\text { mous in } \\
\text { Senate }\end{array}$ & D \\
\hline $\begin{array}{r}2 / 17 / 200 \\
9\end{array}$ & $\begin{array}{l}81(\mathrm{R})- \\
\text { HB } 266\end{array}$ & $\begin{array}{l}\text { Regulating the provision } \\
\text { of benefits and services } \\
\text { to, and the verification of } \\
\text { the employment status } \\
\text { of, immigrants and to } \\
\text { enforcing laws relating } \\
\text { to immigrants; providing } \\
\text { civil and criminal } \\
\text { penalties. }\end{array}$ & $\begin{array}{l}\text { Employ- } \\
\text { ment } \\
\text { verificatio, } \\
\text { Immigra- } \\
\text { tion status, } \\
\text { Civil and } \\
\text { criminal } \\
\text { penalties }\end{array}$ & $\begin{array}{l}\text { Not } \\
\text { passed }\end{array}$ & & $\mathrm{R}$ \\
\hline $\begin{array}{r}3 / 13 / 200 \\
9\end{array}$ & $\begin{array}{l}81(\mathrm{R})- \\
\text { HB } 4482\end{array}$ & $\begin{array}{l}\text { A requirement of lawful } \\
\text { presence in the United } \\
\text { States for receipt of state } \\
\text { educational benefits and } \\
\text { to the determination of } \\
\text { resident status of } \\
\text { students by public } \\
\text { institutions of higher } \\
\text { education. }\end{array}$ & $\begin{array}{l}\text { Lawful } \\
\text { Presence, } \\
\text { Education }\end{array}$ & $\begin{array}{l}\text { Not } \\
\text { passed }\end{array}$ & & $\mathrm{R}$ \\
\hline $\begin{array}{r}3 / 10 / 200 \\
9 \\
\end{array}$ & $\begin{array}{l}81(\mathrm{R})- \\
\text { SB } 1677\end{array}$ & $\begin{array}{l}\text { The regulation of } \\
\text { immigration assistance } \\
\text { services; providing civil } \\
\text { and criminal penalties. }\end{array}$ & $\begin{array}{l}\text { Immigra- } \\
\text { tion } \\
\text { Assistance } \\
\text { Services } \\
\end{array}$ & $\begin{array}{l}\text { Not } \\
\text { passed }\end{array}$ & & $\mathrm{D}$ \\
\hline $\begin{array}{r}4 / 29 / 200 \\
9 \\
\end{array}$ & $\begin{array}{l}81(\mathrm{R})- \\
\text { SB } 2568\end{array}$ & $\begin{array}{l}\text { A prohibition against the } \\
\text { knowing employment of } \\
\text { persons not lawfully } \\
\text { present in the United } \\
\text { States and the suspension } \\
\text { of licenses held by } \\
\text { certain employers for the } \\
\text { knowing employment of } \\
\text { those persons. }\end{array}$ & $\begin{array}{l}\text { Emplo- } \\
\text { yment } \\
\text { Verifica- } \\
\text { tion, } \\
\text { Immigra- } \\
\text { tion status }\end{array}$ & $\begin{array}{l}\text { Not } \\
\text { passed }\end{array}$ & & $\mathrm{R}$ \\
\hline
\end{tabular}

Table 2 shows the immigration-related bills introduced during the 2009 legislative session. It also shows that most bills (4 out of 5) did not pass. The character of the only bill that passed was not anti-immigrant per se; it perhaps supported immigrant rights since it dealt with interpretation services in the health care system, an issue that often comes up in regard to the Spanish-speaking 
population of Texas. This bill was introduced by a Democrat, as was another bill that did not pass and was related to immigration assistance services and false advertisement —in a sense, an immigration-friendly bill as well. Three bills that dealt with employment verification, introduced by Republican legislators, did not pass.

More telling is that fact that only five immigration-related bills were introduced in the 2009-a small number considering Texas' role in the national immigration debate and the fact that other states forged ahead with a record number of immigration-related bills. State legislators across the country introduced approximately 1500 immigration-related bills and resolutions, according to the National Conference of State Legislatures (NCSL 2009). The same 2009 NCSL report shows that Texas' bills related to education (tuition eligibility), health care (interpreters), human trafficking (assistance to victims), and a few other topics. There was no omnibus bill in Texas, as there were in Georgia, Missouri, and Nebraska that year. The 2009 immigration landscape in Texas appears to have been relatively benign compared to the aggressive legislative environment in many other states.

Table 3 shows the major immigrant and immigration-related bills introduced in the Texas state legislature in 2011. Fourteen bills were introduced during the 2011 legislative session. Of these, half (7) passed and half (7) were defeated. 
The Immigration Debate in Texas

Table 3. Immigration-related bills introduced by Texas legislators in 2011

\begin{tabular}{|c|c|c|c|c|c|c|}
\hline $\begin{array}{r}\text { Date of } \\
\text { Introduction } \\
\text { (Filed) }\end{array}$ & $\begin{array}{l}\text { Legislation } \\
\text { ID }\end{array}$ & Description & Keywords & $\begin{array}{l}\text { Passed/Not } \\
\text { Passed }\end{array}$ & $\begin{array}{l}\text { Ratio For / } \\
\text { Against }\end{array}$ & Party \\
\hline $1 / 31 / 2011$ & $\begin{array}{l}81(\mathrm{R})- \\
\text { SB } 84\end{array}$ & $\begin{array}{l}\text { Relating to requiring } \\
\text { governmental entities } \\
\text { and contractors with } \\
\text { governmental entities to } \\
\text { participate in the federal } \\
\text { electronic verification of } \\
\text { work authorization } \\
\text { program, or E-verify. }\end{array}$ & $\begin{array}{l}\text { Employment } \\
\text { Verification, } \\
\text { Immigration } \\
\text { Status }\end{array}$ & Not passed & & $\mathrm{R}$ \\
\hline $2 / 22 / 2011$ & $\begin{array}{l}82(\mathrm{R})- \\
\mathrm{HB} 12\end{array}$ & $\begin{array}{l}\text { Vote to pass a bill that } \\
\text { outlines the enforcement } \\
\text { of state and federal } \\
\text { immigration laws by } \\
\text { certain governmental } \\
\text { entities. }\end{array}$ & $\begin{array}{l}\text { Enforcement } \\
\text { of Federal } \\
\text { Immigration } \\
\text { laws, } \\
\text { Immigration } \\
\text { Status, } \\
\text { Information } \\
\text { Sharing } \\
\end{array}$ & Not passed & & $\mathrm{R}$ \\
\hline 2/9/2011 & $\begin{array}{l}82(\mathrm{R})- \\
\text { HB } 1202\end{array}$ & $\begin{array}{l}\text { Makes it illegal to } \\
\text { "intentionally, } \\
\text { knowingly, or } \\
\text { recklessly" employ an } \\
\text { "unauthorized alien"; } \\
\text { employ/contract for labor } \\
\text { or other work; } \\
\text { employ/contract labor or } \\
\text { other work of someone } \\
\text { who will use } \\
\text { "unauthorized aliens" }\end{array}$ & $\begin{array}{l}\text { Employment, } \\
\text { Contracts, } \\
\text { Verification of } \\
\text { Immigration } \\
\text { Status }\end{array}$ & Not passed & & $\mathrm{R}$ \\
\hline $3 / 9 / 2011$ & $\begin{array}{l}82(\mathrm{R})- \\
\text { HB } 2734\end{array}$ & $\begin{array}{l}\text { Relating to certain } \\
\text { mandatory conditions of } \\
\text { parole or mandatory } \\
\text { supervision for illegal } \\
\text { criminal aliens and the } \\
\text { revocation of parole or } \\
\text { mandatory supervision as } \\
\text { a result of violating those } \\
\text { conditions. }\end{array}$ & $\begin{array}{l}\text { Aliens; } \\
\text { Corrections - } \\
\text { Parole, } \\
\text { Probation, \& } \\
\text { Pardons; } \\
\text { Mandatory } \\
\text { and } \\
\text { Community } \\
\text { Supervision }\end{array}$ & $\begin{array}{l}\text { Passed } \\
\text { (Both) }\end{array}$ & $\begin{array}{l}146 / 0 \\
\text { (House); } \\
30 / 1 \\
\text { (Senate) }\end{array}$ & $\mathrm{R}$ \\
\hline $2 / 17 / 2011$ & $\begin{array}{l}82(R)- \\
\text { SB } 11\end{array}$ & $\begin{array}{l}\text { Relating to the } \\
\text { enforcement of state and } \\
\text { federal laws governing } \\
\text { immigration by certain } \\
\text { governmental entities. }\end{array}$ & $\begin{array}{l}\text { Immigration, } \\
\text { Enforcement; } \\
\text { State and } \\
\text { Federal } \\
\text { Immigration } \\
\text { Laws, } \\
\text { Information- } \\
\text { Sharing }\end{array}$ & Not passed & & $\mathrm{R}$ \\
\hline
\end{tabular}


The Immigration Debate in Texas

\begin{tabular}{|c|c|c|c|c|c|c|}
\hline $1 / 31 / 2011$ & $\begin{array}{l}82(\mathrm{R}) \text { - } \\
\text { SB } 124\end{array}$ & $\begin{array}{l}\text { Relating to the } \\
\text { enforcement of state and } \\
\text { federal laws governing } \\
\text { immigration by certain } \\
\text { governmental entities; } \\
\text { providing a civil penalty. }\end{array}$ & $\begin{array}{l}\text { Enforcement, } \\
\text { State and } \\
\text { Federal Laws, } \\
\text { Information- } \\
\text { sharing, Civil } \\
\text { Penalties }\end{array}$ & Not passed & & $\mathrm{R}$ \\
\hline $3 / 3 / 2011$ & $\begin{array}{l}82(\mathrm{R})- \\
\text { SB } 1124\end{array}$ & $\begin{array}{l}\text { This act requires } \\
\text { applicants for residential } \\
\text { mortgages to submit a } \\
\text { completed application } \\
\text { through the Nationwide } \\
\text { Mortgage Licensing } \\
\text { System and Registry and } \\
\text { establish to the } \\
\text { satisfaction of the } \\
\text { commissioner that s/he is } \\
\text { a citizen of the United } \\
\text { States or a lawfully } \\
\text { admitted alien. }\end{array}$ & $\begin{array}{l}\text { Mortgage, } \\
\text { Housing }\end{array}$ & Passed & $\begin{array}{l}\text { Unanimous } \\
\text { in both }\end{array}$ & $\mathrm{R}$ \\
\hline $7 / 3 / 1905$ & $\begin{array}{l}82(\mathrm{R})- \\
\text { SB } 1254\end{array}$ & $\begin{array}{l}\text { Relating to the creation } \\
\text { of the offense of } \\
\text { employing an individual } \\
\text { not lawfully present in } \\
\text { the United States. }\end{array}$ & $\begin{array}{l}\text { Immigration, } \\
\text { Status, } \\
\text { Resident } \\
\text { Verification, } \\
\text { Employment } \\
\text { Verification } \\
\end{array}$ & Not passed & & $\mathrm{R}$ \\
\hline $11 / 8 / 2010$ & $\begin{array}{l}82(\mathrm{R})- \\
\text { SB } 150\end{array}$ & $\begin{array}{l}\text { This act grants the } \\
\text { Special Agents of the } \\
\text { United States } \\
\text { Immigration and } \\
\text { Customs Enforcement } \\
\text { authority to have the } \\
\text { powers of arrest, search, } \\
\text { and seizure under the } \\
\text { laws of this state as to } \\
\text { felony offenses. }\end{array}$ & $\begin{array}{l}\text { Law } \\
\text { Enforcement } \\
\text { Cooperation } \\
\text { and Authority }\end{array}$ & Passed & $\begin{array}{l}\text { Unanimous } \\
\text { in both }\end{array}$ & D \\
\hline $11 / 8 / 2010$ & $\begin{array}{l}82(\mathrm{R})- \\
\text { SB } 150\end{array}$ & $\begin{array}{l}\text { Relating to granting } \\
\text { limited state law } \\
\text { enforcement authority to } \\
\text { special agents of the } \\
\text { Office of Inspector } \\
\text { General of the United } \\
\text { States Department of } \\
\text { Veterans Affairs and to } \\
\text { updating certain } \\
\text { references related to the } \\
\text { grant of that authority to } \\
\text { other federal law } \\
\text { enforcement personnel. }\end{array}$ & $\begin{array}{l}\text { Law } \\
\text { Enforcement }\end{array}$ & & & \\
\hline $3 / 11 / 2011$ & $\begin{array}{l}82(R)- \\
\text { SB } 1698\end{array}$ & $\begin{array}{l}\text { Relating to reporting } \\
\text { concerning inmates who } \\
\text { are confined in county } \\
\text { jails and subject to } \\
\text { federal immigration } \\
\text { detainers. }\end{array}$ & $\begin{array}{l}\text { Immigration, } \\
\text { Jails, } \\
\text { Detentions }\end{array}$ & Passed & & $\mathrm{R}$ \\
\hline
\end{tabular}


The Immigration Debate in Texas

\begin{tabular}{|c|c|c|c|c|c|}
\hline $12 / 15 / 2011$ & $\begin{array}{l}82(\mathrm{R})- \\
\text { SB } 259\end{array}$ & $\begin{array}{l}\text { Relating to the duty of a } \\
\text { peace officer to inquire } \\
\text { into the immigration } \\
\text { status of persons arrested } \\
\text { on other grounds. }\end{array}$ & $\begin{array}{l}\text { Immigration, } \\
\text { Status, } \\
\text { Arrests, Status } \\
\text { Verification }\end{array}$ & Not passed & $\mathrm{R}$ \\
\hline $2 / 7 / 2011$ & $\begin{array}{l}82(\mathrm{R})- \\
\text { SB } 530\end{array}$ & $\begin{array}{l}\text { Relating to granting } \\
\text { limited state law } \\
\text { enforcement authority to } \\
\text { special agents of the } \\
\text { Office of Inspector } \\
\text { General of the United } \\
\text { States Social Security } \\
\text { Administration and to } \\
\text { updating certain } \\
\text { references related to the } \\
\text { grant of that authority to } \\
\text { other federal law } \\
\text { enforcement personnel. }\end{array}$ & $\begin{array}{l}\text { Immigration, } \\
\text { Customs, Law } \\
\text { Enforcement, } \\
\text { Arrests, } \\
\text { Felony, } \\
\text { Detention, } \\
\text { Probable } \\
\text { Cause and } \\
\text { Immigration } \\
\text { Status }\end{array}$ & Passed & $\mathrm{R}$ \\
\hline $3 / 3 / 2011$ & $\begin{array}{l}82(\mathrm{R})- \\
\text { SB } 9\end{array}$ & $\begin{array}{l}\text { Relating to the } \\
\text { enforcement of state and } \\
\text { federal laws governing } \\
\text { immigration by certain } \\
\text { governmental entities } \\
\text { and the administration of } \\
\text { certain documentation of } \\
\text { citizenship status and } \\
\text { other lawful admittance } \\
\text { by the Department of } \\
\text { Public Safety of the State } \\
\text { of Texas. }\end{array}$ & $\begin{array}{l}\text { Law } \\
\text { Enforcement, } \\
\text { Identification, } \\
\text { Immigration } \\
\text { Status } \\
\text { Verification, } \\
\text { Driver's } \\
\text { License }\end{array}$ & Passed & $\mathrm{R}$ \\
\hline
\end{tabular}

Of the 14 bills introduced by Texas legislators in 2011, many were related to law enforcement, immigration status, and employment verification; and one related to housing/mortgage eligibility. As stated above, seven of the 14 bills passed. The successful bills were primarily related to law enforcement; one was related to mortgage eligibility verification. Some of the provisions that passed were not as radical as those introduced in other states, even though some were clearly directed at enforcing immigration laws. Interestingly, ant-immigrant rhetoric was largely absent during the debate of these bills. It is unclear whether the laws have been thoroughly enforced, however; that will require a separate study.

Running the analysis of the legislation through a second variable — political party—all initiatives were introduced by Republicans, with the exception of one, SB-150, which was introduced by a Democrat. This bill granted U.S. Customs agents arrest, search, and seizure power under the laws of Texas for felony offenses. 
What is puzzling about the 2009 and 2011 Texas legislative sessions is that both were overwhelmingly dominated by the Republican Party; even so, the Republican Party of Texas did not show a collective willingness to push aggressive legislative immigration reforms. Thus, even though Texas Republicans introduced most of the anti-immigration proposals, the party as a whole balked at supporting them; the majority of the bills did not make it out of committee. Table 4 shows the overwhelming dominance of the Republican Party in the Texas legislative sessions under consideration in this paper.

Table 4. Partisan Composition of the 82nd and 83rd Legislative Sessions in Texas

\begin{tabular}{|c|c|c|c|c|}
\hline & \multicolumn{2}{|c|}{$\begin{array}{l}\text { Texas 81st Legislative } \\
\text { Session, } 2009\end{array}$} & \multicolumn{2}{|c|}{$\begin{array}{c}\text { Texas 82nd Legislative } \\
\text { Session, } 2011\end{array}$} \\
\hline & $\begin{array}{c}\text { House of } \\
\text { Representa- } \\
\text { tives }\end{array}$ & Senate & $\begin{array}{c}\text { House of } \\
\text { Representa- } \\
\text { tives }\end{array}$ & Senate \\
\hline Affiliation & & & & \\
\hline $\begin{array}{l}\text { Republican } \\
\text { Party }\end{array}$ & 76 & 19 & 101 & 19 \\
\hline $\begin{array}{l}\text { Democratic } \\
\text { Party }\end{array}$ & 74 & 12 & 49 & 12 \\
\hline Total & 150 & 31 & 150 & 31 \\
\hline
\end{tabular}

The relevance of the dominance of the Republican Party in the Texas legislature would not be of interest were it not for the fact that the party in many other states is strongly associated with antiimmigrant legislation, such as the SB-1070 in Arizona.

Moreover, the inability or unwillingness of the Texas Republican Party to pass harsh antiimmigration legislation points to the fact that the party itself may be divided. In other words, the issue of immigration has driven a wedge in the Texas Republican Party between the Tea Party conservatives and the vibrant Texas business community-the former is quite hostile to immigrants but is unable to prevail over the more tolerant business wing of the Republican Party, which appears to value immigration for economic reasons. 


\section{The 287(g) Program and Sanctuary City Resolutions}

U.S. Immigration and Customs Enforcement (ICE), responsible for implementing immigration laws, has relied on Section $287(\mathrm{~g})$ of the Illegal Immigration Reform and Immigrant Responsibility Act of 1996 to establish a series of collaborative agreements with local law enforcement to detect undocumented residents and detain them until ICE can make an appearance to process them for deportation. Through the 287(g) programs, ICE effectively delegated immigration enforcement authority to public safety agencies at the local level, essentially deputizing local law enforcement officers as immigration agents. City police departments and county sheriff offices in several dozen communities entered into 287(g) agreements with ICE across the United States. Further confirming the relatively moderate position of the state in regard to immigration, only three local law enforcement agencies in Texas entered into such agreements: The police departments in Farmers Branch and Carrollton (near Dallas, Texas) and Harris County (Houston). No other community law enforcement agencies in Texas appeared to have been willing to enter into such agreements.

The number of $287(\mathrm{~g})$ agreements in the United States was not large in any case, as local law enforcement agencies feared their deputized role as immigration agents would deter citizens from reporting crime in their communities. The number of agreements does appear to be particularly low in Texas, however, given the state's central role as a transit region for undocumented residents and as the residence of over 1.5 million undocumented residents. The fact that only three local governments out of 4,856 entered into $287(\mathrm{~g})$ agreements is indicative of the unwillingness of Texas to participate in the anti-immigration wave that swept state and local governments after 2005.

However, a number of local governments in Texas did pass sanctuary city resolutions (Table 5). A sanctuary city resolution is a written policy - an ordinance, a declaration, or administrative action by local government officials - that prevents local employees from notifying federal authorities on the immigration status of a person they come into contact with or detain. The policy makes no distinction between a legal and undocumented presence; it treats everyone the same. The policy makes a city or town an effective safe haven for undocumented residents. An 
Internet search shows that at least 15 Texas cities, including Houston, Dallas, and San Antonio, have passed sanctuary city resolutions - several times more cities, and with considerably larger populations, than the places that entered into $287(\mathrm{~g})$ agreements. In fact, while Dallas is considered a sanctuary city, two of its suburbs, Carrollton and Farmers Branch, have signed 287(g) agreements with ICE. Most cities in Texas took a less visible and controversial approach, neither committing to $287(\mathrm{~g})$ agreements nor passing sanctuary city resolutions.

Table 5. Texas cities that have passed sanctuary city resolutions

\begin{tabular}{|l}
\hline - Austin, TX \\
- Baytown, TX \\
- Channelview, TX \\
- Denton, TX \\
- El Cenizo, TX \\
- Ft.Worth, TX \\
- Houston, TX \\
- Laty, TX \\
- League City, TX \\
- Mcallen, TX \\
- Port Arthiney, TX \\
San Antonio, TX \\
\hline
\end{tabular}

The fact that in spite of the well-known Republican character of the state, a number of Texas cities passed sanctuary city resolutions signals that the state's relationship to immigration is mixed. While strong anti-immigrant sentiments do exist in Texas, state leaders appear to take a more pragmatic approach to immigration, even undocumented immigration, preferring to view it as linked to the economic vitality of the state.

In order to understand this attitude, it is necessary to stay alert to the words of politicians and the political mood of the state in general. During his opening remarks at the 2011 legislative session, Gov. Rick Perry called for abolishing sanctuary cities in Texas. He also called for a crackdown on immigration. In May 2011, a bill was introduced to ban Texas governmental entities from adopting policies to protect undocumented residents. But in spite of an overwhelming 
Republican majority in both houses of the Texas legislature, the state failed to pass any laws abolishing sanctuary cities - although legislation allowing a policy to inquire on the immigration status of lawfully detained individuals did pass. During his opening remarks at the 2013 legislative session, Perry did not mention the issue of immigration at all.

\section{The 2013 Legislative Session and the Post-electoral Scenario in Texas}

Public opinion varies considerably in regard to undocumented migration in the United States. Why specific individuals or groups hold more liberal attitudes than others is not well understood (Espenshade, et al. 1993). It is also difficult to establish how public opinion translates into public involvement in policy decision-making, though some researchers have proposed innovative methods to understand that transition (Hampton 2009). Sorting out why Texas has turned out to be relatively liberal in its attitudes toward immigration in spite of Republican Party dominance can help us understand this general theoretical puzzle. Indeed, Texas' moderate position is somewhat counterintuitive in light of the fact that the state is considered relatively conservative; that its national voting record since the 1990s has made it a nearly solidly red state; and that the Republican Party has dominated nearly every statewide office as well as the state legislature, with majorities sufficient to pass nearly any legislation it wished; and that the Republican Party elsewhere has been associated more closely with anti-immigration legislation than the Democratic Party.

This section breaks down this apparent paradox. I hypothesize that the rather moderate position that Texas has embraced in regard to immigration may be directly related to the changing demographic dynamics of the state - particularly its rapidly growing Hispanic population, which, according to the U.S. Census Bureau, reached 38.1 percent in 2011 — and the national political context, as crystallized in the November 2012 elections. Combined, these factors may prove helpful to understanding why the rhetoric in the state has changed, and why Tea Party loyalists have not effectively won over the state as it has Arizona and other states. In order to understand the position of the state of Texas, we have to consider not only statewide legislation and local $287(\mathrm{~g})$ agreements sanctuary city resolutions, but also the more subjective dynamics of politics and other factors unique to Texas, as well as the national political context. 


\section{Changing Demographics and the Latino Vote}

As already stated, the Latino population of Texas reached 38.1 percent in 2011, according to the U.S. Census Bureau. It is also clear that it is growing much faster than other demographic groups in the state. And even though their political power has not been realized because many are not citizens and the share of their vote is lower than their overall numbers in the state population, their numbers are growing so fast they will eventually have enormous electoral influence. That Latinos lean Democratic in Texas, however, is not a surprise. The 26 counties that went Democratic in the 2012 presidential election are counties where Hispanics are a majority or a first plurality. Thus, even though the Republican Party held onto 228 out of 254 counties, there was a direct correlation between Hispanic majority or plurality counties and a vote for the Democratic Party (Figure 1). In addition, 70 percent of all Texas Latinos voted for Obama and only 29 percent voted for Mitt Romney - a number comparable to the national vote, which was 71 percent for Obama and 27 percent for Romney. Texas Republicans cannot easily ignore Latino demographics and the voting tendencies of Latinos. As mentioned above, Perry-who had asked for a crackdown on immigration during the 81st legislative session in 2011-did not mention the immigration issue at all during the opening remarks of the 82nd legislative session in 2013. In addition, Perry clearly stated during the 2011 Texas legislative session that sanctuary cities should be abolished in Texas, but made no mention of sanctuary cities during the opening of the 2013 Texas session. 
Figure 1. Texas Counties and the Electoral Breakdown of November 2012.

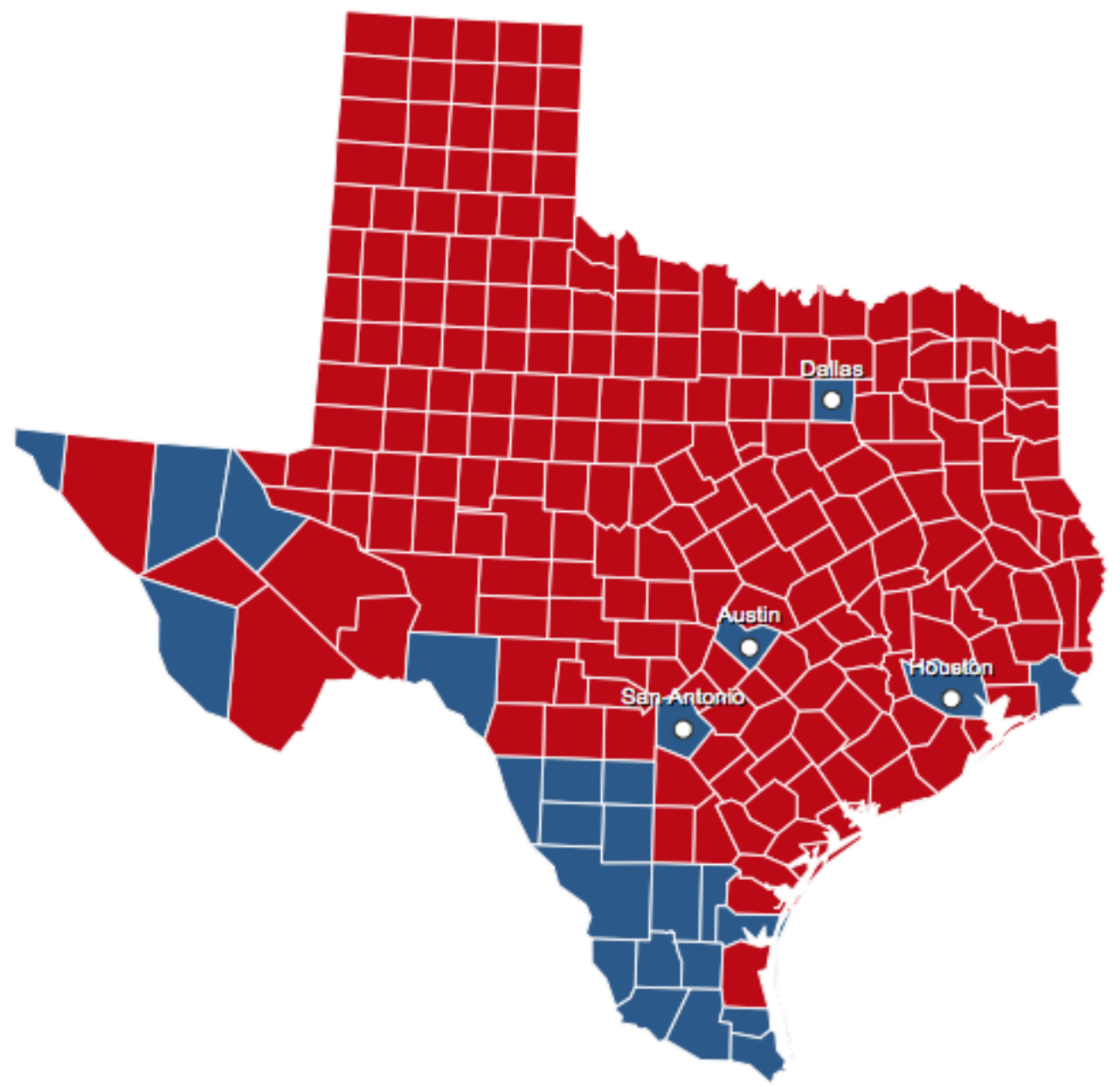

Source: www.nbcnews.com.

As Figure 1 illustrates, only 26 of the 254 counties in Texas voted Democratic in 2012. Romney received 57.2 percent of the vote compared with 41.4 percent for Obama. Look beyond the general numbers, however, to the voting tendencies of Latinos and the demographic composition of the counties that went Democratic. If a solid victory in Texas emboldened the Republican Party to make further calls for an immigration crackdown, a deeper analysis of the demographic composition of the state and the electoral results cooled such temptation. 


\section{The National Context and Texas' Stands on Immigration}

It would be difficult to maintain that Texas' position on immigration changed after the November 2012 election-even if Perry's post-electoral silence is telling and likely the result of his reading of the 2012 election results. It is more than clear that Texas' overall position vis-à-vis immigration issues had already exhibited a remarkable degree of moderation well before the 2012 elections. This is well demonstrated in the analysis above, and the general reading of the results support that conclusion. But there is greater depth to Perry's nearly complete lack of public interest in the current immigration debate in Washington. The governor should be openly advocating for changes in the immigration system that would be beneficial to the state. His relative silence reveals that he finds it a more convenient response, partly because he does not want to alienate the Republican Party base and partly because he understands that the party cannot continue to do well in Texas in the long term were it to take a tough stand on immigration. Thus, Texas' moderate position on immigration appears to be a pragmatic result of balancing political forces in the state. This is not an unreasonable position to take and corresponds to the generally liberal attitude that Texas has had toward immigration over the long term.

The Texas position in regard to immigration cannot be separated from national voting results, the Hispanic vote landslide in favor of Obama, and the growing Hispanic population in Texas. These developments do not bode well for the Republican Party and explain to a large extent the silence of Texas state politicians in regard to the immigration debate in the spring of 2013. Although some Texas politicians have declared their opposition to a path to citizenship for undocumented residents - mostly those who draw their support from the Tea Party - the Republican Party has staked out a more moderate position as a whole.

In addition, the 2013 legislative session has not seen any of the more contentious immigration bills that were introduced in the 2011 legislative session. The word "immigration" has hardly come up during this session. Perry did not mention immigration in his January 2013 State of the State address, although he did address the border. This silence from both legislators and Perry's

office is telling, and speaks to the political shift within the Republican Party in Texas. It further 
reinforces the more tolerant discourse present in the more moderate wing of the party well before the November 2012 elections. The three-to-one margin in the November 2012 elections was essentially a reminder of the coming power of the Hispanic vote and the need of the Republican Party to appeal to that electoral segment if it is to maintain its majority in the state of Texas.

Minorities today represent nine out of every 10 new residents in Texas, putting further pressure on the Republican Party to adapt to the new demographic reality of the state. This, of course, means that the Republicans will have to weigh the influence of their more conservative base (social conservatives) with the influence of their more tolerant wing (business) and the rapidly growing power of minorities in the electorate. This will not be easy, however. Even if the hardline talk on immigration has quieted, the Republican Party will not easily tone down its antiimmigration rhetoric, given that its weapons against Democratic candidates often include references to undocumented residents and the insecurity of the border. The Republican Party will have to find a different way of rallying its conservative base, without alienating the growing Hispanic population. In addition, the Democrats are already counting on the Hispanic base to recover its electoral competitiveness statewide. Mayor Julian Castro of San Antonio is one of the most outspoken leaders in the Democratic Party and has a determination to make the Hispanic vote in Texas count.

\section{Public Policy Implications}

Few policy implications can be drawn from a study of Texas and immigration. This is because the states are not generally in charge of immigration, and immigration-related initiatives in recent years were both unusual and a response to the failure of the federal government to deal with the issue.

A key implication, however, is that a proposed immigration bill in Washington will likely contain large prescriptions on border security. There is no apparent agreement on what constitutes a secure border. But states like Texas have much to say about that. The rhetoric should be stripped from the issue and conservatives should stop using border security as a rallying cry. Instead, a clear measure on border security should be crafted. The definition of a 
secure border should be determined more scientifically and less rhetorically and to that end, the state of Texas has much to say. As it designs policies to secure the border, the federal government should tap the expertise of border states, whose experience on the issue is vast.

In addition, the Texas business community, which has been the most tolerant wing of the Republican Party, has useful experience related to the importance of low- and mid-skilled labor in the U.S. economy. These lessons should not be ignored by legislators in Washington. In crafting a potential guest worker program - as Congress appears poised to do - the federal government should consider the needs of the states and their economies, and allow the states to determine to a large extent their labor needs and the number of visas needed for their specific industries. The types and numbers of visas can be indexed to the economic needs, and the industries present, in each state.

\section{Conclusion}

Texas has exhibited remarkable moderation when it comes to undocumented migration and the presence of undocumented residents in the state. This is puzzling, given the fact that Texas' politics is dominated by the Republican Party, which is closely associated with anti-immigration policies in other states. The situation is compounded by the fact that Texas constitutes half of the U.S.-Mexico border and it is the transit zone for many of the undocumented residents in the United States as well as home to the second-largest number of undocumented residents. Finally, the state's moderate stance is perplexing given the relative violence that the Mexican side of the border has experienced in the last six years and the constant threat of a spillover-however real or imagined.

This moderation is well demonstrated in the relatively low number of immigration-related bills introduced in Austin and the largely rhetoric-free legislative debates. Several anti-immigrant bills were introduced in the Texas legislature in 2009 and 2011, but most were defeated-although Republicans could have passed them at any time. The moderation is also evident in the low number of $287(\mathrm{~g})$ agreements signed - only three, which contrasts with the higher number of Texas cities that declared themselves sanctuary cities for undocumented residents. 
Finally, the rhetoric of the Texas Republican Party shows its ambivalence in regard to the issue. There is plenty of anti-immigration rhetoric in the party, but it seldom translates into actual policies at the state level. It is simply impractical for the party to push anti-immigration legislation that will continue to alienate the Hispanic population, which is growing rapidly throughout the state. In that sense, the Republican Party has simply shifted to silence. This silence may be strategic because it stops the hemorrhage of Hispanic votes, particularly after the November 2012 elections, without necessarily alienating much of its conservative base. Silence appears to be a strategic choice, at least while the party crafts its strategy vis-à-vis the Hispanic population of the state and the country. 
The Immigration Debate in Texas

\section{Bibliography}

Cianciarulo, M.S. 2012. “The ‘Arizonification’ of Immigration Law: Implications of Chamber of Commerce v. Whiting for State and Local Immigration Legislation.” Harvard Latino Law Review 15: 8-128.

Espenshade, T.J, C.A. Calhoun. 1993. “An Analysis of Public Opinion Toward Undocumented Immigration.” Population Research and Policy Review 12: 189-24.

Hampton, G. 2009. "Narrative Policy Analysis and the Integration of Public Involvement in Decision Making.” Policy Sciences 42: 227-242.

Jeong, G., G. J. Miller, C. Schofield, and I. Sened. 2011. “Cracks in the Opposition: Immigration as a Wedge Issue for the Reagan Coalition.” American Journal of Political Science 55:3 (July): 511-525.

National Conference of State Legislatures. 2009. "2009 State Laws Related to Immigrants and Immigration.” Available at http://www.ncsl.org/issues-research/immig/2009-stateimmigration-laws.aspx.

Passel, J. and D’V. Cohn. 2009. “A Portrait of Unauthorized Immigrants in the United States. The Pew Hispanic Center Report.” April 12. Available at http://www.pewhispanic.org/files/reports/133.pdf. 